\title{
Zwarte Pieten, moskeebezoek en zoenende mannen
}

\section{Katholiek activisme van Cultuur onder Vuur en de culturalisering van religie}

\author{
Markus Balkenhol \& Ernst van den Hemel*
}

Religion and tradition play a central role in the polarized debates concerning Dutch national identity. In reaction to perceived threats, the maintenance and protection of religious roots and cultural traditions are framed as crucial elements of Dutch society. These appeals on 'Christian culture' and 'Judeo-Christian roots' are the sites of new alliances and divisions. It is not uncommon to see secular, even outspoken atheist actors allying with conservative religious actors. But what precisely is meant by these actors when they claim to protect national religious culture? In this paper we look at three cases in which the Catholic foundation Civitas Christiana has engaged in these debates: one campaign for the safeguarding of Black Pete, one against primary school excursions to mosques, and one against homosexual image$r y$ in the public sphere. While secular groups applauded the first two campaigns, they rejected the one against homosexual imagery. These campaigns and their successes and failures, illustrate how the politics of religion, secularity, and the nation play out in ethnographic detail.

\section{Introductie}

De Zwarte Piet-controverse woedde in alle hevigheid toen in 2015 in $D e$ Volkskrant een artikel verscheen waarin de 'stille kracht' achter de populaire campagne 'Red Zwarte Piet' aan het woord kwam. Hoewel de campagne veel aandacht kreeg, zullen weinig mensen Civitas Christiana noch de doelstellingen van de katholieke stichting kennen. Toch bleek de organisatie een belangrijke faciliterende rol achter de schermen gespeeld te hebben.

* Markus Balkenhol en Ernst van den Hemel zijn als post-doctorale onderzoekers verbonden aan het Meertens Instituut. 


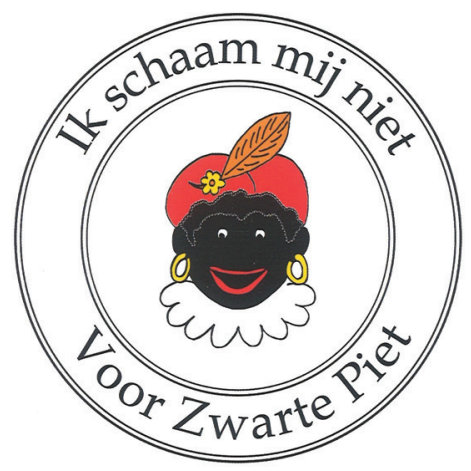

Onder de naam van haar campagnebureau 'Cultuur onder Vuur' nam Civitas Christiana het voortouw bij onder meer het lanceren van de actie 'Red Zwarte Piet.' De stichting kwam met een petitie die door 200.000 mensen ondertekend werd. Er werden honderdduizenden flyers gedrukt die in De Telegraaf gevouwen werden en de stichting stuurde duizenden brieven en kaarten (zie illustratie) met daarin de oproep te doneren want: 'Zwarte Piet heeft u nodig!'

Daarnaast ontwikkelde Cultuur onder Vuur een lespakket, waarin docenten een handreiking kregen om de onderliggende waarden en geschiedenis achter Zwarte Piet over te brengen. Het Volkskrant-artikel concludeerde dat deze stichting een belangrijke rol speelde bij het aanjagen en organiseren van het kamp dat Zwarte Piet wil behouden.

Civitas Christiana treedt vaker op als aanjager van maatschappelijk controversiële discussies. Momenteel is dezelfde stichting bezig met een campagne waarin het 'verplicht moskeebezoek door scholen' bekritiseerd wordt. Volgens de omschrijving van de campagne gaat het hierbij om 'indoctrinatie' en 'voorbereiding op bekering' waar vele scholen zich schuldig aan maken. Deze campagne, die onder andere door middel van een crowdsourcing-actie in kaart brengt wanneer scholen moskeeën hebben bezocht, kan rekenen op aanzienlijke aandacht in de politiek, landelijke media en sociale media. Zo schreef Wierd Duk van De Telegraaf hier meerdere artikelen over ${ }^{1}$, werd op GeenStijl enthousiast over het dossier bericht ${ }^{2}$ en werd het aangelegde dossier van Cultuur onder Vuur besproken in de Tweede Kamer.3 Op 7 november 2018 werd een motie aangenomen op basis van het rapport van Cultuur onder Vuur waardoor deelname aan excursies naar moskeeën mag worden geweigerd.

Ook een derde campagne leidde tot maatschappelijke ophef. In maart 2018 liet de stichting 40.000 kaartjes in het Reformatorisch Dagblad vouwen waarin bezwaar gemaakt werd tegen de 'pornografische reclames' van modemerk 
Suit Supply. In deze reclames waren twee zoenende mannen te zien, wat volgens de stichting aanstootgevend en gevaarlijk voor kinderen is.

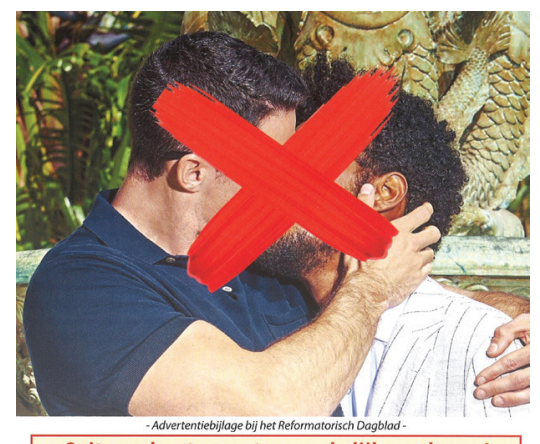

Suitsupply, stop met onsmakelijke reclames! Teken nu de petitie aan Fokke de Jong, eigenaar van Suitsupply

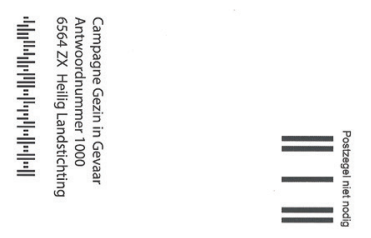

Maar, waar de campagnes over Zwarte Piet en Verplicht Moskeebezoek een alliantie teweeg brachten met mainstream rechtse media in Nederland, zoals GeenStijl en De Telegraaf, werd deze campagne door dezelfde media met behoorlijk wat minder enthousiasme ontvangen. GeenStijl stak de draak met 'religieuze extremisten die beleid willen maken en partijprogramma's schrijven met de hand op een boekje' en adresseerde leider Hugo Bos als volgt: 'Nou Hugo Bos, dikke creep, weet je wat ook een uitermate vulgaire afbeelding is die niet te zien zou mogen zijn in het publieke domein?' en voegde een hyperlink toe naar een portret van Hugo Bos zelf. ${ }^{4}$

Cultuur onder Vuur is kortom een opvallende speler in gepolariseerd Nederland. Regelmatig worden de campagnes van Cultuur onder Vuur door grote media-spelers en partijen omarmd, gedeeld of aanbevolen. Bepaalde andere aspecten van het werk van de stichting worden echter door dezelfde groepen stevig afgewezen. Het in het oog springende werk van en de opvallend diverse allianties rondom Cultuur onder Vuur leggen een aantal interessante vragen bloot over de rijk geschakeerde onrust over de 'christelijke cultuur' van Nederland. Wat zegt het over onze tijd, waarin ontkerkelijking hoogtij viert, dat een beroep op de christelijke cultuur in het middelpunt van maatschappelijke controverses terechtkomt? Hoe verhouden de campagnes van de stichting zich tot andere partijen en organisaties die zeggen op te komen voor de christelijke identiteit van Nederland, zoals politieke partijen als PVV en de VVD? Welke rol speelt religie in deze controverses?

Om deze vragen te kunnen beantwoorden analyseren wij de drie hierboven genoemde campagnes die in 2018 tot ophef hebben geleid: 'Zwarte Piet', 'Verplicht Moskeebezoek' en 'Suit Supply'. Deze drie campagnes speelden allemaal recentelijk en hebben alle drie tot aanzienlijke landelijke ophef en invloed geleid. We bekijken hoe verwijzingen naar 'christelijke cultuur' in 
deze campagnes ingezet worden en, door te kijken naar de receptie van deze campagnes, hoe Cultuur onder Vuur in staat is om verschillende maatschappelijke spelers aan te spreken. Daarmee presenteren we een inkijkje in hoe referenties aan de 'christelijke cultuur' ingevuld worden in tijden van hernieuwde interesse in de nationale identiteit en in- en uitsluiting. In de conclusie laten we zien dat Cultuur onder Vuur onderdeel is van nieuwe maatschappelijke verhoudingen in Nederland waarvoor de tweedeling seculier-religieus maar zeer beperkt bruikbaar is. Maar eerst geven we kort wat achtergrondinformatie over de stichting Cultuur onder Vuur.

\section{Civitas Christiana / Cultuur onder Vuur / Traditie, Familie, Privé- bezit}

Cultuur onder Vuur is de naam waaronder de stichting Civitas Christiana actie voert. Civitas Christiania is weer onderdeel van de internationale beweging Tradition, Family, and Property (TFP). De grondlegger van de beweging was Plinio Corrêa de Oliveira (1908-1995), wiens werk zich richtte op het beschermen van de christelijke beschaving. De Oliveira schreef tijdens een groot gedeelte van de tweede helft van de twintigste eeuw activistische analyses waarin de aanval wordt geopend op 'vals universalisme', de gevaren van communisme en het belang van 'contra-revolutionair engagement.' Dit zien we in de organisatie die De Oliveira oprichtte in 1960, The Brazilian Society for the Defense of Tradition, Family and Property. De tientallen organisaties over de hele wereld die zich op TFP beroepen, leggen de nadruk op cultuur en traditie in hun engagement. Activisme op basis van deze overtuiging wordt door de stichting al enkele decennia uitgevoerd in onder meer Frankrijk, Polen en de Verenigde Staten. Zo kent The American Society for the Defense of Tradition, Family and Property zichzelf een belangrijke positie toe aan de 'front lines of the Culture War.' In Polen verbindt dit gedachtegoed zich aan de opkomst van Pools nationalisme en anti-Europa sentimenten. ${ }^{5}$ Bij dit activisme hoeft de nadruk niet te liggen op bekering maar eerder op het beschermen van 'de christelijke beschaving', 'cultuur' en 'tradities.' Of zoals Hugo Bos het in het Volkskrant-artikel schetste: 'Opus Dei richt zich op het verspreiden van geloof, wij verspreiden beschaving.'

Waar TFP en Civitas Christiana in landen als Polen en de Verenigde Staten al langer maatschappelijk actief zijn, werd pas in 2014 de tijd rijp geacht voor een Nederlandse tak van deze conservatief-activistische katholieke stichting. 
Zoals we zullen aantonen blijken aspecten van dit katholiek conservatieve activisme succesvol in Nederland ( $\mathrm{al}$ is het binnen bepaalde parameters). Een sceptische lezer zou kunnen zeggen dat het hier puur opportunisme rondom reeds bestaande polarisatie betreft. Wij denken echter dat het succes van Cultuur onder Vuur wijst op een belangrijk en zelden bestudeerd aspect van de hedendaagse maatschappij. In tijden van culturele polarisatie worden nieuwe groepen gevormd, en oude scheidslijnen (zoals links en rechts, religieus en seculier) voldoen niet meer om het politieke landschap te beschrijven. Dat betekent ook dat een conservatief-katholieke stichting zich in het midden van maatschappelijke controverses kan begeven. En bovendien slaagt zij erin diverse groepen aan zich te binden. Het appel op het beschermen van de christelijke cultuur van Nederland kan, zoals blijkt uit de campagnes, rekenen op behoorlijk brede maatschappelijke steun. Om te begrijpen hoe dit in zijn werk gaat, bekijken we hoe deze campagnes in staat zijn verschillende segmenten aan te spreken. Wellicht het meest succesvolle voorbeeld hiervan is de campagne rondom Zwarte Piet. Cultuur onder Vuur presenteert de kritiek op Zwarte Piet als een kritiek op de Nederlandse christelijke cultuur. Het activisme van Cultuur onder Vuur op dit onderwerp bleek populair. Maar, is Zwarte Piet eigenlijk wel een symbool van de Nederlandse christelijke cultuur?

\section{Sinterklaas als christelijk én seculier feest?}

De actievoerders van Cultuur onder Vuur benadrukken in hun communicatie dat het beschermen van Zwarte Piet een strijd voor het behoud van de christelijke cultuur in Nederland is. Maar wat wordt daarmee bedoeld?

Ten eerste is het de vraag of het Sinterklaasfeest 'religieus' genoemd kan worden. Alhoewel de goedheiligman, bij leven (omstreeks $280-342$ of 352) de bisschop van Myra, historisch gezien een van de belangrijkere katholieke heiligen is, is het niet zo evident dat het huidige Sinterklaasfeest een christelijk feest betreft. Anders dan met Kerst, waarbij menig familie naar de kerk gaat, of Pasen, waar de Matthäus Passion in de kerk of de paasdienst een geliefde activiteit vormt, is er bij Sinterklaas geen noemenswaardige koppeling met geïnstitutionaliseerde religie. In de Sinterklaasliedjes wordt bijvoorbeeld melding gemaakt van kerk noch Bijbel, God noch Jezus, en tijdens de intocht of het Sinterklaasjournaal wordt het feest niet direct in een christelijke traditie geplaatst. Deze profane dimensie van het Sinterklaasfeest heeft diepe wortels. ${ }^{6}$ 
Al vanaf de veertiende eeuw vonden op de feestdag van de heilige Nicolaas handelingen plaats die het zuiver devotionele overstegen (Boer-Dirks 1993, 4). Vanaf de zeventiende eeuw zijn er uitgebreide beschrijvingen van de profane elementen van het in huislijke kring gevierde Sinterklaasfeest zoals we deze ook nu nog kennen: het schoen zetten, speelgoed en lekkers (appels, noten, vijgen, rozijnen, en zelfs geld) (Boer-Dirks 1993, 4). Sint-Nicolaas is, zeker vandaag de dag, misschien wel in de eerste plaats een 'volks'heilige, en zijn rol als devotionele heilige is daaraan ondergeschikt (Boer 2009). Deze ontwikkeling versnelde in de achttiende en negentiende eeuw. Onder de druk van verlichte opvoedkundige idealen werd het geloof in een fictief figuur gezien als leugen en bedrog. Het zou de kinderen van hun 'verstand' beroven en afgoderij en bijgeloof in de hand werken. John Helsloot wijst erop dat er zelfs werd 'gepleit om het feest af te schaffen' (Helsloot 2008, 97). In de twintigste eeuw, met de ontzuiling die in de jaren 1950 begon, werd het Sinterklaasfeest verder ontkerkelijkt. Vandaag de dag is het Sinterklaasfeest geen devotionele viering meer, en heeft voor velen maar zeer beperkt een religieuze betekenis.

Een ander opvallend aspect aan het claimen van het Sinterklaasfeest als onderdeel van de christelijke cultuur van Nederland wordt duidelijk als we vragen welk christendom er met 'christelijk' wordt bedoeld, zeker omdat het Sinterklaasfeest in de loop van zijn bestaan vooral ook een strijdtoneel is geweest tussen protestanten en katholieken. Tijdens de Reformatie stond het Sinterklaasfeest als een te wantrouwen, want immers rooms-katholiek, feest te boek. De protestantse hardliners zagen het feest als ongeoorloofde verering van beelden en keurden het daarom in de sterkste bewoordingen af:

Met niet aflatende ijver stelden magistraten en predikanten - uiteindelijk tevergeefs gebleken - pogingen in het werk om die "Pauselyke superstitie niet in de jonge kinderen te planten maar uytteroyen". De Goudse predikant Jacobus Sceperus valt in zijn Geschenck op geseijde St. Nicolaes Avont (1658) pagina's lang venijnig uit naar dat paapse feest, "immers alles is Bedroch, Leugen en Valscheyt" (Boer-Dirks 1993, 4).

De protestantse ijver zorgde ervoor dat de profane dimensies van het feest, namelijk vooral het vieren in huiselijke kring met cadeau's en surprises, belangrijker dan de devotionele viering werden. Sint-Nicolaas kon vaak niet meer in de kerk worden gevierd, en moest ontdaan worden van openlijk devotionele attributen. Paradoxaal genoeg heeft deze profanisering ervoor gezorgd dat het feest, met haar seculiere vorm als het ware als dekmantel, kon 
overleven (Boer 2009). Kortom, het betreft een van oorsprong katholiek feest, dat lange tijd vanuit protestants-christelijke kant is aangevallen. Dat maakt een typering van het feest als algemeen 'christelijk' opvallend.

Na de protestantse kritiek, de opkomst van verlichte opvoedkundige idealen en de relatief radicale ontzuiling en ontkerkelijking (zie hieronder) is het niet verrassend dat het Sinterklaasfeest ook tegenwoordig niet primair als confessioneel feest gezien wordt. Dit zien we bijvoorbeeld terug in de omschrijvingen die van het Sinterklaasfeest gegeven worden. Zelfs de grootste voorstanders van Sinterklaas en Zwarte Piet verbinden het feest zelden aan het christendom in de confessionele zin van het woord. Zo heeft het 'Sint en Pietengilde' met succes ervoor gevochten dat het Sinterklaasfeest (inclusief Zwarte Piet), in de inventaris immaterieel erfgoed terechtkwam. In de omschrijving in de inventaris wordt het feest gedefinieerd als 'een feest voor alle leeftijden [dat] bestaat uit een aantal rituelen en gebruiken'. Het gaat hier om: intocht, schoen zetten, pakjesavond en het zingen van Sinterklaasliedjes. In geen van deze uitingen wordt verwezen naar religie, en afgezien van de omschrijving van Sinterklaas als een bisschop en heilige wordt vooral de nadruk op de volkse aard van het feest gelegd.

In het licht van dit alles is het opvallend dat een conservatief katholieke stichting, wier doelstelling het is om de christelijke cultuur van Nederland te beschermen, het voortouw neemt in het beschermen van Zwarte Piet. Het zou eerder voor de hand liggen om kerkbezoek, Pasen of Kerstmis op te voeren als pijlers van de christelijke cultuur. Is hier sprake van een activisme dat zich slechts voor de gelegenheid verbindt aan de Zwarte Piet-controverse? Of gebeurt er meer op het gebied van 'christelijke cultuur' in Nederland? Om dit te begrijpen is meer toelichting vereist over de betekenissen die aan cultuur en religie gegeven worden. Specifiek is het van belang om te omschrijven hoe tegen de achtergrond van debatten over nationale identiteit het spreken over christelijke cultuur een centrale politieke categorie werd.

\section{Alledaagse cultuur als christelijke cultuur? Culturalisering van de Nederlandse identiteit}

Christelijke cultuur, joods-christelijke tradities of wortels, zijn termen die in Nederland tegenwoordig in ruime kring gebruikt worden om een breed thuisgevoel aan te duiden. In plaats van een verwijzing naar confessionele 
religieuze tradities of geloofsopvattingen is het in hedendaags Nederland veelvoorkomend om over de Nederlandse cultuur in de breedste zin van het woord als christelijk te spreken (Van den Hemel 2018). Dit komt specifiek op in tijden van onzekerheid over en zoektocht naar wat een nationale samenleving bindt (Geschiere 2008; Roodenburg 2012). Hierbij kan een scala aan gebruiken en rituelen verheven worden tot bedreigd symbool van nationale identiteit (Stengs 2012, 13). Om dit proces te begrijpen stelden sociologen voor om het begrip 'culturalisering' te gebruiken.

Volgens de sociologen Evelien Tonkens en Jan Willem Duyvendak is culturalisering een recent fenomeen dat na de Tweede Wereldoorlog opkwam. Daarvóór werd burgerschap begrepen in termen van rechten en plichten die het lidmaatschap in een natie met zich meebrengt. Het ging hierbij om grondrechten zoals de vrijheid van meningsuiting en religie, maar ook het recht op eigendom en het recht om contracten te tekenen en voor de rechtbank te verschijnen. Maar burgerschap, begrepen als de mogelijkheid tot maatschappelijke en politieke deelname is ook verbonden aan culturele waarden en patronen. De baan die iemand kan uitoefenen hangt af van bijvoorbeeld zijn of haar opleidingsniveau, of, in de termen van de Franse socioloog Pierre Bourdieu (1986), van het cultureel kapitaal, zoals de toegang tot en vertrouwdheid met culturele instituties als musea, bibliotheken, scholen, en media. In de recente ontwikkelingen in het denken en beleid rondom burgerschap is deze culturele dimensie steeds meer centraal komen te staan. Tonkens en Duyvendak constateren nu dat het nieuwe idee van burgerschap tegenwoordig 'minder gevat [wordt] in termen van burgerlijke, politieke, of sociale rechten, en meer in termen van het naleven van normen, waarden, en culturele praktijken' (Duyvendak et al 2016, 2).

Cultuur is in dit proces een normatief begrip geworden: minderheden worden steeds meer geacht zich aan te passen aan een dominante, 'Nederlandse' cultuur. Zo wordt steeds vaker over 'de Nederlandse cultuur' gesproken, waarvan verondersteld wordt dat deze onverenigbaar is met (bepaalde) andere culturen. In dit denkkader wordt een religie als de islam als 'cultuur' begrepen die lijnrecht tegenover de 'Nederlandse cultuur' staat. Deze eis roept natuurlijk de vraag op naar definities. Als minderheden zich moeten aanpassen, moet wel duidelijk zijn waaraan ze zich moeten aanpassen (Geschiere 2008). Dat heeft geresulteerd in een brede zoektocht naar wat echt en typisch Nederlands is (Roodenburg 2012). In dit kader worden ook met grote regelmaat de christelijke cultuur, joods-christelijke wortels, of tradities genoemd.

Zo wijzen momenteel de drie grootste partijen in Nederland op het belang van de (joods-)christelijke cultuur. De PVV wil al sinds haar oprichting 
verwijzingen naar het belang van de joods-christelijke cultuur opnemen in de grondwet (als vervanging van artikel 1), de VVD heeft in 2008 het belang van een gedeelde joods-christelijke traditie in haar beginselverklaring opgenomen, en ook het CDA spreekt over het belang van een brede christelijke cultuur. Religie is wellicht wel het meest populaire, maar tegelijkertijd vaagomlijnde, register om te spreken over wat de historische wortels en actuele achtergrond zijn van de Nederlandse cultuur (Van den Hemel 2017a). Bij het schetsen van de christelijke cultuur wordt, op zijn zachtst gezegd, vaak een nogal breed penseel gehanteerd. Zo definieerde de PVV de christelijke cultuur als 'opkomen voor het eigen volk', heeft liberale premier Rutte paaseitjes tot symbool van de christelijke nationale identiteit verheven, en sprak Buma, toen hem gevraagd werd deze christelijke waarden wat nader te preciseren, over 'zaken die we hier al duizenden jaren hebben, zoals gelijkheid tussen man en vrouw.'7

Opvallend aan dit proces is dat de culturalisering van burgerschap gepaard gaat met het samenvoegen van aspecten van de Nederlandse geschiedenis die voorheen gescheiden waren. Zo zien we dat de geschiedenis van de verzuiling als een geschiedenis van consensus wordt gezien. Seculiere waarden zoals grondrechten en vrijheden worden plots als joods-christelijk bestempeld. Bij het proces van culturalisering wordt een breed palet aan positieve waarden en geschiedenissen als typisch Nederlands aangeduid. Er wordt hierbij nogal wat strijd en onenigheid weggepoetst. Het begrip 'joods-christelijk' is hier een voorbeeld van: waar de Europese geschiedenis zich vaak kenmerkt door antisemitisme en door tegenstellingen tussen het christendom en jodendom, en tussen de verschillende varianten van het christendom, wordt deze geschiedenis nu als een gedeelde cultuur en gedeeld thuis opgevoerd. De zoektocht naar 'Nederlandsheid' heeft met zich meegebracht dat verschijnselen die vijftig jaar geleden nog omstreden waren, nu gedefinieerd worden als typisch Nederlands.

Zo wordt bijvoorbeeld het secularisme begrepen als iets typisch Nederlands. Dit is opmerkelijk omdat Nederland tot in de jaren 1950 een van de meest religieuze samenlevingen in Europa was (Van der Veer 2006). Na een stevig en onstuimig proces van ontkerkelijking wordt een kritische houding ten opzichte van kerk en geloof nu vaak aangehaald als een typisch Nederlandse waarde. Een van de meest prominente manieren om dit te doen is door te refereren aan seksuele emancipatie. Met name sinds de seksuele revolutie in de jaren zestig van de vorige eeuw is seks een van de belangrijkste vormen van openbare religiekritiek geworden. Dit geldt ook voor de emancipatie van 
vrouwen en homoseksuelen. Wat ooit een emancipatoire en controversiële ontwikkeling was, wordt nu gezien als volbracht. Emancipatie is daarmee niet langer een streven maar een normatieve eis en een beschrijving van hoe typische Nederlanders zich gedragen. Het gevolg: wie Nederlander wil zijn, moet openlijk uitdragen dat deze principes gedeeld worden. Zoals Paul Mepschen et al. het verwoorden: 'sexual freedom has come to stand, metonymically, for secularism and rational, liberal subjectivity' (Mepschen et al. 2016, 964).

Het gaat ons hier niet om een oordeel over deze ontwikkeling te vellen. Eerder willen wij aangeven dat met deze culturalisering het politieke landschap ingrijpend veranderd is. Wat recent nog scandaleus was, wordt nu gepresenteerd als wezenskenmerk van het Nederlandse volk. Politieke strijd in het verleden wordt nu glad gestreken als een geschiedenis van consensus. Doordat dit brede beeld van Nederland samengevat wordt als 'christelijke cultuur' wordt het voor mensen die zich niet als religieus identificeren mogelijk om toch op te komen voor 'de christelijke cultuur' van Nederland. Zo kan het dat de liberale VVD bij het belang van joods-christelijke cultuur seculiere waarden aanhaalt, zo kan het dat de PVV aangeeft dat homo-tolerantie onderdeel is van onze joods-christelijke cultuur, en zo is het te begrijpen dat politici als Thierry Baudet atheïsme als onderdeel van de superieure christelijke cultuur zien.

De hierboven geconstateerde context is nodig om te begrijpen hoe in onze casus, het activisme van Cultuur onder Vuur ter bescherming van de christelijke cultuur, over de christelijke cultuur gesproken wordt en hoe daarbij brede instemming van ogenschijnlijk tegenstrijdige partijen/groeperingen kan worden verkregen. Aan de ene kant, zoals we zullen zien, betekent de opkomst van culturalisering dat verwijzingen naar de christelijke cultuur niet meer geassocieerd worden met kerkelijke stoffigheid, maar met het beschermen van de Nederlandse identiteit in de breedste zin van het woord. Aan de andere kant leggen juist deze brede aspecten van het spreken over 'de christelijke cultuur', waar dus zowel religieuze als seculiere elementen onder gerekend worden, ook de grenzen van deze allianties bloot. Maar laten we eerst kijken naar de allianties.

\section{Civitas Christiana, religie en islamofobie}

Tegen de achtergrond van culturalisering, waarbij christelijke cultuur gebruikt wordt om over nationale identiteit en cultuur te spreken, moeten we 
het taalgebruik van Cultuur onder Vuur rondom Zwarte Piet plaatsen. Zo lag de nadruk in de eerste campagne van de stichting voor het behoud van Zwarte Piet in 2014 op de christelijke cultuur, maar daarmee wordt eerder een brede Nederlandse identiteit aangeduid dan een confessionele stroming:

Onze gemeenschap verliest zo een traditie die ons samenbindt en die een belangrijk onderdeel uitmaakt van onze Nederlandse identiteit. ${ }^{8}$

Het Sinterklaasfeest - en Zwarte Piet in het bijzonder - wordt hier voorgesteld als een bindmiddel dat voorkomt dat de Nederlandse samenleving uit elkaar valt. Ook in haar protestbrief aan de minister-president, Mark Rutte, riep Cultuur onder Vuur op tot het behoud van de 'Nederlandse cultuur':

Zwarte Piet maakt echter al sinds eeuwen deel uit van het leven van ons als Nederlanders. We verwachten van $u$ als Nederlandse regering dat $u$ het voor de Nederlandse cultuur opneemt. Dat $u$ niet de vijanden van de Nederlandse cultuur halfweg tegemoet gaat, maar dat $u$ hun namens ons het hoofd biedt. ${ }^{9}$

Cultuur onder Vuur zo lezen wij op haar website, presenteert het christendom als essentieel om te begrijpen wat Nederlands is:

Wij begrijpen de Nederlandse cultuur in de context van de christelijke beschaving, zoals die in de loop der eeuwen in Europa vorm heeft gekregen. Als grondleggende principes van de Europese cultuur zien wij traditie, familie en privé-eigendom.

Ook de verwijzingen naar de christelijke cultuur als breed gedeeld thuisgevoel past hierbij. Het is het soort taalgebruik dat prima binnen een bredere rechtse beweging in Nederland past. Zie bijvoorbeeld hoe de opvattingen over cultuur aanwezig zijn in het activisme rondom Zwarte Piet:

Als de voorgestelde verandering van Zwarte Piet doorgang vindt, dan betekent dit een breuk met de wijze waarop het feest voorheen beleefd werd. Bovendien impliceert het dat Nederland eeuwenlang een racistisch volksfeest heeft gevierd, waar alle generaties voor ons zich schuldig aan hebben gemaakt. Onze cultuur, waar wij trots op zijn, wordt resoluut op één lijn gesteld met racisme. Dit zou bijzonder kwalijk zijn. ${ }^{10}$

Dit activisme van Civitas Christiana rondom Zwarte Piet werd actief gedeeld door PVV, VVD en GeenStijl. Dit is niet zo verwonderlijk. Ook de PVV 
koppelt Zwarte Piet aan de joods-christelijke wortels van Nederland. ${ }^{11}$ En ook de VVD spreekt over de aanval op Kerstmis, Pasen en Zwarte Piet als aanvallen op de christelijke cultuur van Nederland. ${ }^{12}$ En op GeenStijl wordt, met de gebruikelijke ironie, gesproken over 'Zwarte Pieten, zoals het hoort volgens de joods-christelijke cultuur.'13

Toch is het de vraag in hoeverre deze gedeelde terminologie ook duidt op gedeelde opvattingen. De doelen, het behoud van Zwarte Piet, maar belangrijker nog, het behoud van de cultuur van Nederland, lijken dezelfde. Vallen het verlangen naar het brede thuisgevoel en de confessionele grondslagen van de stichting naadloos samen? Of is hier sprake van een complexer fenomeen? Laten we daarom eens kort kijken naar andere campagnes van de stichting.

\section{De campagne tegen 'Verplicht moskeebezoek'}

Cultuur onder Vuur heeft sinds 2017 een campagne opgezet tegen 'verplicht moskeebezoek door scholen'. Het doelwit van de campagne zijn excursies van basisscholen naar moskeeën. Op de website van Cultuur onder Vuur is een filmpje te zien waarin giechelende kinderen in een moskee ervaren hoe het is om te bidden als moslim. De imam maakt grapjes over de juiste gebedshouding. Terwijl de kinderen knielend met het voorhoofd aan de grond 'bidden' zegt de imam: 'blijft u maar zo [voorover gebogen], ik ga koffie drinken!' Volgens Cultuur onder Vuur is dit een voorbeeld van de indoctrinatie en voorbode van islamisering en moeten dergelijke bezoeken onmiddellijk stoppen:

De Nederlandse schoolkinderen worden door de imam geïnstrueerd te knielen en de islamitische geloofsbelijdenis te bidden. De eerste stap naar bekering tot de islam is gezet. ${ }^{14}$

De gewraakte bezoeken aan moskeeën zijn onderdeel van programma's waarmee scholieren kennis opdoen van verschillendevormen van geloof. Hetis onderdeel van het 'kerndoel 38', opgesteld door de Stichting Leerplanpontwikkeling (SLO), het nationaal expertisecentrum voor leerplanontwikkeling. Het kerndoel is onderdeel van het vak 'mens en samenleving', hoofdstuk 'oriëntatie op jezelf en de wereld', en wordt als volgt verwoord: 
De leerlingen leren hoofdzaken over geestelijke stromingen die in de Nederlandse multiculturele samenleving een belangrijke rol spelen, en ze leren respectvol om te gaan met seksualiteit en met diversiteit binnen de samenleving, waaronder seksuele diversiteit. ${ }^{15}$

Het bezoeken van kerken, synagogen en moskeeën vormt daarin een regulier onderdeel. De doelen van deze bezoeken zijn er op gericht om kinderen inzicht te geven in de verschillende (geloofs)stromingen in Nederland.

Het argument van Cultuur onder Vuur tegen deze bezoeken lijkt tweeledig te zijn. Zo stelt de stichting dat in een aantal van de bezochte moskeeën radicaal gedachtegoed gepreekt wordt. Maar het probleem ligt volgens Cultuur onder Vuur niet in uitwassen. 'Verplichte' bezoeken aan moskeeën, en het deelnemen aan rituelen, wordt überhaupt als indoctrinatie opgevat en daarom verworpen. Zo worden kinderen bijvoorbeeld volgens Cultuur onder Vuur bij het betreden van moskeeën onderworpen aan een 'rigoureuze scheiding van de geslachten'. Cultuur onder Vuur vindt dit schokkend en ongewenst:

Deze waanzin moet onmiddellijk stoppen. Teken nu de petitie tegen dit knielen en 'bidden' in de moskee. Nederlandse schoolkinderen moeten verre van islamitische indoctrinatie blijven! ${ }^{16}$

Ook deze campagne is gretig gedeeld door diverse spelers aan de rechterflank in Nederland. In De Telegraaf wordt de campagne gezien als 'opstand van bezorgde ouders', op GeenStijl verschijnt een artikel met de titel 'Schoolkinderen op verplicht moskeebezoek: ouders met bezwaar hebben pech', waarin het rapport van Cultuur onder Vuur gedeeld wordt: 'Basisschoolkindjes die in hun extra-kwetsbare vormingsjaren alvast maatschappelijk voorgevormd worden tot welwillende Avondlanders, netjes op de knieën want islam betekent immers onderwerping. ${ }^{17}$ In de berichtgeving van GeenStijl wordt niet genoemd dat de moskeebezoeken onderdeel zijn van bredere leerdoelen waarin meerdere geloofsgemeenschappen bezocht worden, in de berichtgeving van De Telegraaf wordt wel vermeld dat er sprake is van 'kerndoel 38', maar daarbij wordt aangegeven dat Cultuur onder Vuur vermoedt 'dat kerkbezoek er nogal eens bij inschiet.' Wat blijft staan is dat moskeebezoek voorbereiding op onderwerping betekent. De Telegraaf haalt de Amerikaanse islam-criticus Robert Spencer aan die spreekt van 'heimelijke jihad. ${ }^{3} 8$ 
Het voorbeeld van het verplicht moskeebezoek wordt gebruikt om stelling te nemen in een belangrijke kwestie: wat is de plaats van de islam naast andere religies in Nederland? Geldt de gelijkheid van religies of moeten die religies die als cultureel eigen gezien worden meer aandacht krijgen? Cultuur onder Vuur verwoordt het als volgt:

We durven tegenwoordig geen verschil meer te maken tussen diverse culturen en religies. De Nederlandse cultuur en tradities zijn gelijk aan die van Ghana en Papoea-Nieuw-Guinea, om maar een paar landen te noemen (...). Alle culturen zijn gelijk, en daarom, onder het mom van neutraliteit, promoot de Nederlandse overheid de Islamitische cultuur evenzeer als de Nederlandse cultuur die op het Christendom is gebaseerd. Deze totalitaire gelijkheidsdwang moet stoppen. De Nederlandse cultuur is niet gelijk aan die van een willekeurig Afrikaans land, niet omdat ze per definitie beter is, maar omdat het de Nederlandse cultuur is. En het is een van de taken van de overheid om die cultuur te beschermen tegen soms gewelddadige activisten die deze cultuur kapot willen maken. ${ }^{19}$

We zien hier een duidelijke illustratie van het effect van culturalisering. Het christendom wordt hier niet gepresenteerd als een religie naast andere religies in seculier Nederland, maar als historische wortel en bestaansvoorwaarde van de Nederlandse cultuur. De islam is, in deze denkwijze, niet een religie die door Nederlanders wordt aangehangen, het is een vreemde cultuur die niet gepromoot moet worden omdat dit afbreuk zou doen aan de waardering en samenhang van de Nederlandse samenleving. Het 'voortrekken' van de Nederlandse cultuur is volgens deze redenering geen discriminatie, maar een logisch antwoord op het dilemma van culturele incompatibiliteit. Of, in begrijpelijker Nederlands, de 'autochtone' Nederlandse bevolking hoeft zich niet aan te passen aan nieuwkomers, nieuwkomers moeten zich aanpassen aan de Nederlandse cultuur, anders blijft er geen Nederland over. Aan deze redenering ligt een specifiek begrip van cultuur ten grondslag. Er wordt namelijk niet alleen vanuit gegaan dat culturen op bepaalde punten verschillen, maar dat ze principieel verschillend zijn. Volgens dat idee bestaan er homogene, onveranderlijke en vast omlijnde 'culturen' die duidelijk van elkaar gescheiden zijn. 'De islam' wordt afgewezen als een cultuur, of zelfs ideologie, die wezenlijk verschilt van de Nederlandse (als christelijk betitelde) cultuur, en daarmee uiteindelijk onverenigbaar is. De islam wordt verbeeld als een cultuur die van elders naar Nederland komt, en dus niet van 'Nederlandse bodem' is. 
De opvatting van cultuur die hieruit spreekt wordt in recent sociaalwetenschappelijk onderzoek als 'nativisme' omschreven (Balkenhol 2016; Mudde 2007, 18-20). Het gaat daarbij niet alleen om de vraag waar mensen geboren zijn. In de nativistische beleving kan iemand in bijvoorbeeld Nederland geboren zijn, maar niet deel uitmaken van de Nederlandse cultuur die als het ware 'inheems' is. In de nativistische verbeelding wordt de natie als een thuis voorgesteld - een thuis waarin een bepaald soort mensen woont. Er kunnen gasten worden ontvangen in dit huis, maar deze moeten zich gedragen volgens de culturele regels die de inwoners van het huis hebben opgesteld en die zij op elk moment kunnen aanpassen. Volgens Jan Willem Duyvendak is dit thuisgevoel gebaseerd op een vorm van 'primordial reasoning':

places are owned by 'native' groups who enjoy specific rights (prominent among them the right to feel at home) ...: a fixed place where people belong, a place which is theirs (Duyvendak, 2011, 2).

Het gevolg van deze redenering is dat mensen die als anders worden gezien (of dit nu vanwege religie of uiterlijk is), buitengesloten kunnen worden als 'nieuwkomers' met minder recht van spreken dan de inheemsen. Dit zagen we ook terug in de argumentatie van Cultuur onder Vuur als het gaat om Zwarte Piet:

Jerry Afriyie is hier bijvoorbeeld als immigrant gekomen, en wil ons nu de les lezen over onze eigen cultuur. Het is toch van de zotte ${ }^{\text {?o }}$

En elders schrijft Cultuur onder Vuur over Afriyie:

Denken de Zwarte Piethaters, meestal niet eens in Nederland geboren, nu echt dat zij met deze gesubsidieerde treiterij vriendjes maken bij de Nederlandse bevolking? ${ }^{21}$

'De Nederlandse bevolking' wordt hier tegenover 'de Zwarte Piethaters' gezet. Er wordt in deze argumentatie gebruik gemaakt van een geculturaliseerde definitie van burgerschap. Nederlandse burgers als Afriyie worden niet gezien als gelijkwaardig bezitter van het door de wet gewaarborgde recht op meningsuiting en protest omdat zij 'niet hier geboren' zijn, wat in deze denkwijze inhoudt dat ze minder recht van spreken hebben over wat er in Nederland plaatsvindt. 
Eenzelfde soort zienswijze op cultuur is aanwezig in de campagne rondom 'verplicht' moskeebezoek. In het door Cultuur onder Vuur uitgegeven lespakket over Sinterklaas en Zwarte Piet beroepen ook de auteurs zich op het kerndoel 38 van SLO maar zij houden een andere interpretatie aan dan veel basisscholen. Volgens de auteurs zou dit artikel niet moeten gaan om de 'hoofdzaken over geestelijke stromingen die in de Nederlandse multiculturele samenleving een belangrijke rol spelen' maar meer over het christendom als leidende cultuur in Nederland:

De diepe wortels van dit feest maken het een geschikt thema om kinderen van groep zeven en acht achterom te laten kijken en aan de hand van Sinterklaas en Zwarte Piet de geschiedenis van hun eigen cultuur te onderzoeken (p. 3).

In deze doelstelling wordt duidelijk verwezen naar een 'eigen' cultuur, die volgens Cultuur onder Vuur hetzelfde is voor alle leerlingen van groep 7 en 8 in Nederland. Bij de doelen van het lespakket wordt vervolgens nader gespecificeerd wat deze cultuur precies is. Het lespakket heeft als een van de belangrijkste doelen dat leerlingen onder woorden kunnen brengen 'wat het verband is tussen het Sinterklaasfeest en het christendom' (p. 3). Diepere kennis over het Sinterklaasfeest moet daarbij de kinderen waarden leren 'die karakteristiek zijn voor een christelijke cultuur als de Nederlandse: "Wie zoet is krijgt lekkers, wie stout is de roe." Het goede doen wordt beloond, kwaad doen wordt bestraft' (p. 3). Nederlandse scholieren hebben volgens de stichting één 'eigen' cultuur die eeuwen oud is, en het is de taak van het onderwijs dit volkseigene te bewaren en waardering ervoor te stimuleren.

Voor Cultuur onder Vuur is de Nederlandse cultuur dus heel expliciet een christelijke, en het is op de symbolische slagvelden rondom Zwarte Piet en moskeebezoek waar de Nederlandse cultuur verdedigd moet worden. Deze lezing van de controverses rondom Zwarte Piet en moskeebezoek overlapt met een tendens in meer rechts-conservatieve kringen in Nederland. For the time being lijken zij in hetzelfde kamp in de botsing der beschavingen te strijden. Maar onder de oppervlakte blijken deze overlappende interesses toch wat tegenstrijdiger te zijn dan het lijkt. Wat er onder de christelijke cultuur verstaan wordt, kan fundamenteel verschillen, ook binnen groepen die de opvatting over de Nederlandse cultuur als 'christelijk' delen. 


\section{Civitas Christiana versus Suit Supply: de grenzen van de alliantie}

Zoals we hierboven hebben laten zien heeft Civitas Christiana zich sinds de oprichting in 2014 ontwikkeld tot een platform voor meerdere in het oog springende publiekscampagnes en activisme. Middels flyers, posters, petities en online activisme slaagt de stichting erin om de door haar geagendeerde punten bij veel spelers in politiek en journalistiek Nederland onder de aandacht te brengen. Maar dezelfde methode is niet altijd een gegarandeerd succes. Naast haar actie voor het behoud van Zwarte Piet en tegen moskeebezoek was een campagne die veel aandacht kreeg, gewijd aan een reclamecampagne van het Amsterdamse kledingmerk Suit Supply. Ook hier liet Cultuur onder Vuur flyers drukken en zette zij haar sociale media-kanalen in. Toch leidde deze campagne bij veel van de spelers die de andere campagnes steunden tot kritiek en satire.

Maar eerst even kort de achtergrond: De Suit Supply reclame heeft de slogan 'Don't just fit in. Find your perfect fit', en stemt overeen met de formule van het bedrijf om haute couture voor een relatief lage prijs te verkopen. Vandaar de slagzin: 'een maatpak voor iedereen.' Deze fantasie van vrije toegang tot de modewereld wordt in verband gebracht met de fantasie van seksuele vrijheid. De campagne toont twee mannen die met elkaar flirten, elkaar liefdevol dan wel op erotische wijze aanraken, en met elkaar zoenen. Het feit dat het gaat om een zwarte en een witte man impliceert dat liefde zelfs de grenzen van huidskleur overstijgt. Voor Suit Supply was het 'hoog tijd' voor een campagne die beelden van homoseksualiteit toont, ${ }^{22}$ en volgens de oprichter, Fokke de Jong, heeft het niets te maken met de commercialisering van homoseksualiteit, eerder met de toename van inclusiviteit en tolerantie. ${ }^{23}$

De reacties op deze campagne waren fel. Suit Supply raakte binnen 24 uur 12.000 volgers op Instagram kwijt, en velen dreigden met de boycot van het bedrijf. Het was niet de eerste keer dat Suit Supply in opspraak kwam om een controversiële reclamecampagne. In 2016 haalde het bedrijf het nieuws met een campagne waarin geminiaturiseerde witte mannen in pakken van de naakte borsten van een zwarte vrouw afglijden of aan een half afgeschoven bikinibroekje hangen. In 2014 liet een campagne van het bedrijf aangeklede (zwarte) mannen in pakken met vrouwen in enkel een bikinibroekje zien. Op één van de foto's is een man in pak te zien die met een (eveneens aangeklede, op haar rug liggende) vrouw lijkt te vrijen, en haar daarbij bij haar keel grijpt. 'Sex sells' is klaarblijkelijk een belangrijke pilaar voor het bedrijf. 
Anders dan de eerdere reclames waren de homo-erotische beelden van Suit Supply voor Cultuur onder Vuur een brug te ver. Zij organiseerde een aantal demonstraties, een social media campagne en liet veertigduizend flyers vouwen in het Reformatorisch Dagblad.

Op 10 maart 2018 demonstreerde Civitas Christiana op het stationsplein in Nijmegen tegen de campagne van Suit Supply:

Het grenst aan porno en je laat kinderen van zes jaar daar toch ook niet naar kijken op internet? Waarom dan wel buiten op straat? ${ }^{24}$

Hoewel Hugo Bos, initiatiefnemer van het protest, tegen pornografie in het algemeen is, benadrukt hij dat het hem vooral om het afbeelden van homoseksualiteit te doen is:

Een poster met een zoenende man en vrouw is evenzeer ongepast. Maar dit is wel anders, want ik volg de Bijbel. Daarin staat dat het huwelijk iets is tussen een man en een vrouw. Alle andere huwelijken zijn volgens de Bijbel niet toegestaan. Ook niet om in de buitenlucht te laten zien. ${ }^{25}$

Bos laat zich weinig gelegen liggen aan het feit dat homoseksualiteit beschermd is door de wet. Voor hem weegt het wetboek minder zwaar dan de wet zoals die in zijn ogen door God is gegeven:

Er is een verschil tussen het relatief nieuwe wetboek van Nederland en de tijdloze morele wetten uit de tien geboden. Het homohuwelijk kan wel toegestaan zijn volgens de wet, maar dat maakt voor ons geen verschil. Wij gaan uit van de blijvende, morele principes. ${ }^{26}$

Gezien deze nadruk op de Bijbel is het niet verrassend dat minder-confessionele spelers in het veld van de culturalisering van religie zich distantieerden. Zo wijdde GeenStijl een item aan de 'christengekkies' die zich met middeleeuwse opvattingen belachelijk lieten maken door activisten. ${ }^{27}$ GeenStijl schreef als volgt over de demonstratie :

In Nijmegen gaat complete weggooier en pratende kut Hugo Bos van het katholieke engnekkenclubje Civitas Christiana de straat op om te protesteren tegen die Suit Supply-posters. ... Wat is het toch donders mooi dat sommige mensen compleet dichtgetikt zijn. Bedankt daarvoor, religie. ${ }^{28}$ 
Bij nadere blik wordt duidelijk dat in de alliantie van spelers die de christelijke cultuur beschermen van verschillende agenda's sprake is. Waar in de gevallen van Zwarte Piet en 'verplicht moskeebezoek' er een ogenschijnlijke consensus bestaat over het feit dat het hier gaat om aanvallen op de christelijke cultuur van Nederland, en consensus over de nativistische elementen van deze christelijke cultuur, blijkt dat zodra de verwijzingen naar religie niet bestaan uit brede verwijzingen naar de meerderheidscultuur van Nederland maar expliciet confessioneel worden er van verschillende fracties sprake is.

Deze tweedeling is ook aanwezig bij de andere campagnes. Op de eigen Facebookpagina van Cultuur onder Vuur worden de berichten waarin in algemene termen over de christelijke cultuur gesproken wordt meestal niet bediscussieerd. Onder de berichten waar expliciet verwezen wordt naar het christendom als geloof (i.p.v. als cultuur), wordt opvallend vaak met aversie tegenover religie in het algemeen gereageerd. Over verplicht moskeebezoek bijvoorbeeld zegt een bezoeker: 'Daar moeten ze echt wat aan gaan doen inperking van geloof minimaal via Brussel regelen.' ${ }^{29}$

Zo plaatst de stichting op haar Facebookpagina 'Red Zwarte Piet' op 6 augustus 2018 een verwijzing naar een artikel over de negatieve effecten van ontkerkelijking met daarbij de tekst:

Aangrijpend. De ontkerkelijking is een grote bedreiging voor onze Nederlandse cultuur. We kunnen de islamisering alleen stoppen door terug te keren naar onze christelijke wortels. Daarom: terug naar de kerk! ${ }^{\circ}$

Van de 66 reacties op deze post (geraadpleegd op 1 november 2018) zijn er welgeteld 58 negatief over het idee dat er naar de kerk gegaan moet worden. Reacties bevatten ondermeer: 'Het geloof maakt meer kapot dan je liefhebt, daarom zal ik nooit meer terugkeren tot een geloof!' en: 'Het geloof is de grootste bedreiging voor de mensheid, door de eeuwen heen bewezen' en: 'Alles werd bepaald door de religie. Dat is gelukkig voorbij (...) Het gaat hier $\mathrm{nl}$ niet om behoud van onze religie, het gaat hier om het behoud van onze levensstijl, onze samenleving en onze democratie, gebaseerd op ChristelijkJoodse normen en waarden' en: 'Geen enkel geloof. Leer vragen te stellen en je open te stellen voor antwoorden dan word je wetende' en: 'Jammer dat er steeds weer nieuwe clubjes gelovigen ontstaan!! Dat zou niet móeten.' Kortom, ook onder stukken waarin het werk van Cultuur onder Vuur positief geciteerd wordt, reageert men regelmatig met algemene religiekritiek. Het publiek dat gevormd wordt door het online activisme van Cultuur onder Vuur 
deelt wellicht de zorgen om de cultuur van Nederland, maar staat niet per se positief tegen geloof.

Het is uiteraard de vraag hoe representatief de Facebookpagina, reacties onder artikelen of twitterberichten zijn voor de achterban van Cultuur onder Vuur. Het is bijvoorbeeld goed mogelijk dat de achterban die zich aangesproken voelt door een conservatief katholiek geluid minder aanwezig is op sociale media. Desalniettemin is het opvallend dat er vrijwel volledige consensus is in de commentaren onder de stukken die islamkritisch, pro-Zwarte Piet zijn maar dat wanneer het geloof ter sprake komt er in ieder geval geen eenduidige consensus over het geloof als remedie bestaat en er zelfs van een flinke dosis religiekritiek en atheïsme sprake is. Net zo is het opvallend dat de stichting deze commentaren niet bestrijdt. Ook bij expliciet seculiere interpretaties van hun werk komt de stichting voor zover wij kunnen zien niet in het geweer.

De alliantie tussen seculier-nativistische beschermers van de christelijke cultuur en het katholiek conservatisme zoals dat van Cultuur onder Vuur is, kortom, begrensd. Er lijkt een onbesproken verschil van mening te zijn over de betekenis van de christelijke Nederlandse cultuur. De vraag dient zich aan of er alleen sprake is van een gedeeld vijandsbeeld of dat er ook van een gedeeld toekomstbeeld van 'de Nederlandse cultuur' sprake is. Specifieker nog is het de vraag welke agenda er met het behoud van Zwarte Piet of het afschaffen van 'verplicht moskeebezoek' wordt gediend: is het behoud van Zwarte Piet onderdeel van het behoud van een christelijke cultuur en de uiteindelijke terugkeer naar de kerk of die van een Nederlandse cultuur die religie achter zich gelaten heeft en met religie-allergie reageert op het moment dat het geloof ter sprake wordt gebracht?

\section{Conclusie}

Wat laat deze korte lezing van drie campagnes van Cultuur onder Vuur nu zien? Ten eerste valt de complexe rol van religie in het oog. Het Sinterklaasfeest is allang geen devotioneel feest meer en wordt door velen niet als een religieus feest ervaren. Toch mengt zich een katholieke organisatie zoals Civitas Christiana in de controverse. Wij verklaarden dit door het maatschappelijke succes van een narratief van culturalisering, waarin een gedeelde en onveranderlijke Nederlandse cultuur wordt voorgesteld die diep geworteld is in een joods-christelijke traditie. Religie is in dit narratief tot 'cultuur' geworden en vereist niet noodzakelijk vroomheid. Dat maakt het mogelijk voor mensen 
die zichzelf niet als religieus, of zelfs anti-religieus, beschouwen om op te komen voor 'de christelijke cultuur.' Met andere woorden, we leven in een tijdsgewricht waarin seculier en religieus niet langer de scheidslijnen bepalen. Nieuwe allianties worden langs andere lijnen gevormd. Specifiek zien we hier een vorm van activisme bedrijven die zich richt op de controverse, de vlam-in-de-pan, het symbool dat vorm geeft aan onbehagen. Zo slaagt Cultuur onder Vuur erin verschillende spelers rondom een nativistisch cultuurbegrip bij elkaar te brengen die het - voorlopig - eens lijken te zijn over het gebruik van 'christelijk' of 'joods-christelijk' om deze cultuur te omschrijven. Het vernieuwende aan deze situatie is dat spelers die voorheen diametraal tegenover elkaar stonden, elkaar nu vinden waar het om andere thema's gaat. Beide kanten van deze informele alliantie weten zo een ongekend groot publiek te bereiken.

De verschillende campagnes van Cultuur onder Vuur geven echter ook aan waar de grenzen liggen. De effectiviteit is het hoogst als een heldere out-groep wordt gedefinieerd. In het geval van Zwarte Piet gaat het om mensen die 'ons' als 'racist' wegzetten, in het geval van moskeebezoek gaat het om een 'weg-met-ons' mentaliteit die leidt tot verplichte indoctrinatie in een 'andere cultuur'. Voor beide campagnes geldt dat de 'ander', de Zwarte Piethaters en moslims, als minder Nederlands worden gezien. Het nativisme leent zich in deze campagnes het best voor het trekken van heldere wij/zij-lijnen. Bij de campagne rondom Suit Supply gebeurde er iets anders. Niet alleen was de 'out-group' niet helder omlijnd, de controverse kon ook niet zo makkelijk in nationaal-culturele termen gegoten worden. Immers, zijn twee zoenende homo's of het Amsterdamse bedrijf Suit Supply minder Nederlands? Om het activisme te schragen gebruikte Cultuur onder Vuur vooral confessionele (i.p.v. culturele) retoriek. Waar het plaatsen van cultuur boven de wet inmiddels algemeen geaccepteerd wordt door veel hedendaagse spelers aan rechts-conservatieve zijde, gaat het plaatsen van de Bijbel boven de Grondwet in tegen de principes van diegenen voor wie de christelijke cultuur juist door haar secularisme gedefinieerd wordt. ${ }^{11}$

Dit heeft belangrijke implicaties voor een wetenschappelijk begrip van culturalisering. De wetenschappelijke literatuur over culturalisering heeft de neiging om een tweedeling te schetsen tussen een seculier Nederlands zelfbeeld en een voorgestelde religieuze ander, meestal de islam. Onze analyse laat zien dat het complexer ligt. In plaats van een vast omlijnde groep van mensen die de Nederlandse cultuur willen beschermen zien we het ontstaan 
van tijdelijke allianties die grote invloed kunnen uitoefenen, maar minder duurzaam zijn dan vaak wordt gedacht. De christelijke cultuur lijkt vooral te werken als verwijzing naar een geïdealiseerd homogeen verleden dat heden ten dage bedreigd wordt door buitenstaanders (buitenstaander wordt hierbij veelal nativistisch gedefinieerd; zij die niet hier geboren zijn of op andere wijze niet passen binnen 'onze cultuur'). Het laat daarnaast zien op welke wijze 'cultuur' en 'beschaving' niet worden opgevat als een veranderlijk dynamisch gegeven maar als een onveranderde ononderbroken positieve stroom uit het verleden.

Wat zegt dit nu over ons heden? De culturalisering die we in dit artikel besproken hebben, heeft als gevolg dat er nieuwe mogelijkheden zijn voor engagement dat zich beroept op religie en nationale identiteit. Het laat echter ook de beperkte bandbreedte zien waarin religie weer terugkeert als centrale categorie in het hedendaagse maatschappelijke debat. Er is ruimte voor religieus engagement voor zover deze zich binnen het keurslijf van culturalisering afspeelt. Het is duidelijk dat dit voor Cultuur onder Vuur mogelijkheden biedt om zich te profileren en debatten aan te jagen. Maar de taal van culturalisering spreken betekent ook dat meegewerkt wordt aan een alliantie die voor een belangrijk gedeelte seculiere of zelfs anti-religieuze sentimenten in zich bergt. Het is dan ook de vraag wat deze alliantie in de toekomst op gaat leveren. Levert deze alliantie meer waardering op voor het daadwerkelijke christendom in Nederland (wat de hoop is van Civitas Christiana)? Of betekent dit een toename in seculier nativisme waarmee ook, bijvoorbeeld, orthodox-christelijke stemmen als minder-Nederlands gezien worden?

Het kanaliseren van de zwevende betekenis van 'christelijke cultuur' en de oplopende emoties in nativistische termen is niet zonder risico. In de zomer van 2018 is door de actiegroep 'Rechts in Verzet' actie gevoerd tegen scholen die zich, volgens deze groep, schuldig zouden hebben gemaakt aan het organiseren van 'verplichte' moskeebezoeken. Deze actiegroep kwam in het nieuws door het achterlaten van onthoofde poppen bij een islamitische stichting in Amsterdam. De actiegroep beriep zich expliciet op de klachten die door Cultuur onder Vuur zijn verzameld. Ook rondom Zwarte Piet liepen dit jaar zaken uit de hand. Het is niet gezegd dat daarmee stichtingen als Cultuur onder Vuur verantwoordelijk zijn voor handelingen van actiegroepen als 'Rechts in Verzet', maar er is wel sprake van een maatschappelijk krachtenveld waarbinnen ideeën, taalgebruik en strategieën worden gedeeld. Specifiek de bereidheid om culturele saamhorigheid boven juridische gelijkheid te stellen 
(zoals we hebben gezien is dit een breed gedeeld aspect van de culturalisering van religie in Nederland), kan leiden tot spanningen in de rechtsstaat. ${ }^{2}$

De campagne rondom moskeebezoek heeft geleid tot een aangenomen motie in de Tweede Kamer (7 november 2018). In deze motie wordt geëist dat ouders moeten mogen weigeren deel te nemen aan excursies naar moskeeën. Het roept de vraag op wat de toekomstige interactie met de islam in het onderwijs zal zijn. Gaat het hier om kritiek op het bezoeken van alle gebedshuizen van alle religies? Of is het de opmaat voor een uitzonderingspositie voor 'de islam', als een religie wezensvreemd aan 'de Nederlandse cultuur?'

Het is kortom de vraag hoe het spreken over de christelijke Nederlandse cultuur zich verhoudt ten opzichte van deze complexe krachten. Het is niet evident dat activisme op basis van een breed begrip van de Nederlandse christelijke cultuur de waardering voor christelijke religie verder brengt, het risico is dat er zelfs een tegengestelde agenda gediend wordt. Net zo goed heeft de tendens om brede ideeën over volksidentiteit boven wettelijke gelijkheid te plaatsen mogelijkerwijs verstrekkende gevolgen. Bij zowel de casus Zwarte Piet als die over 'verplicht moskeebezoek' zagen we dat 'buitenstaanders' volgens sommigen niet gelijkelijk behandeld hoeven te worden. Hierbij worden burgerschap en de rechten en plichten die erbij horen afhankelijk gemaakt van een culturele identiteit. Als dit de houding is die bij een meerderheid van de partijen of Nederlanders de handen op elkaar krijgt dan kunnen we een permanente strijd langs religieus-culturele lijnen verwachten. Het zou een goed begin zijn om wat duidelijkheid te krijgen over wat 'de christelijke cultuur' nu precies betekent voor de verschillende spelers in dit debat. Door de verschillen helder te krijgen kan wat nu een vaag omlijnd strijdbegrip is, ingevuld worden met dialoog over de zorgen van verschillende partijen. Hier ligt voor de nabije toekomst een urgente taak voor zowel wetenschappers als politici. 


\section{Noten}

111 juni 2018, https://www.telegraaf.nl/nieuws/215268o/wat-moeten-ze-daar-met-hunneus-in-het-tapijt en o9 juni 2018, https://www.telegraaf.nl/nieuws/2149026/onvredeover-moskee-schoolreis?utm_source=twitter\&utm_medium=referral\&utm_campaign=twitterfeed.

212 juni 2018, https://www.geenstijl.nl/5142444/het-is-geen-onderwerping-als-hetvan-de-leraar-moest/.

35 juni 2018, 'Beantwoording Kamervragen over verplichtmoskeebezoekvoor scholieren', https://www.rijksoverheid.nl/binaries/rijksoverheid/documenten/kamerstukken/ 2018/06/05/beantwoording-kamervragen-over-verplicht-moskeebezoek-voor-scholieren/beantwoording-kamervragen-over-verplicht-moskeebezoek-voor-scholieren.pdf.

49 maart 2018, 'ChristenUnie haat gays. Hugo Bos haat gays' https://www.geenstijl. $\mathrm{nl} / 5141075 /$ christenunie-haat-gays-hugo-bos-haat-gays/.

5 zie bijvoorbeeld de website van het tijdschrift van TFP in Polen: 'Polonia Christiana' https://www.eng.pch24.pl/the-website-pch24-pl,57498,i.html.

6 In de discussie rondom Zwarte Piet wordt juist vaak de niet-christelijke oorsprong benadrukt. De figuur zou juist Germaanse wortels hebben, en bijvoorbeeld afstammen van de zwarte raven Huginn en Muninn die volgens de Germaanse mythologie de god Wodan/Odin op de hoogte hielden van de gang van zaken in de wereld. Het is niet verrassend dat Cultuur onder Vuur, die juist de katholieke wortels van het feest benadrukt, deze lijn van argumentatie niet oppikt. Hier duidt zich al een scheidingslijn aan waar we hieronder dieper op in zullen gaan. Zie ook: http://www.meertens.knaw. $\mathrm{nl} / \mathrm{cms} / \mathrm{nl} /$ onderzoek/faq/145825-vragen-over-zwarte-piet.

7 'Het Carré-debat' RTL4, 5 maart, 2017, https://www.rtl.nl/video/5f65096b-512f-3a6596d8-48f8b75830a8/.

8 https://www.katholieknieuwsblad.nl/component/k2/burgemeester-van-der-laan-redzwarte-piet, geraadpleegd op 12 oktober 2018.

9 https://cultuurondervuur.nu/petitie-aan-mark-rutte-behoud-zwarte-piet/, geraadpleegt op 29-08-2018.

$10 \mathrm{https} / / /$ cultuurondervuur.nu/zwarte-piet-2014/.

11 Zie bijvoorbeeld de Zwarte Piet wet die door de PVV in februari 2017 werd ingediend. https://www.pvv.nl/75-fj-related/harm-beertema/9440-zwarte-piet-wet.html.

12 Zie het 'paaseitjesinterview' van Mark Rutte 22 februari 2017, cf. Ernst van den Hemel 2017a.

13 https://www.geenstijl.nl/4845802/wat_zullen_we_nou_krijgen_uitroepteken_elf/.

14 https://klapuitdeschool.nl/hoorn-bidden-moskee/, geraadpleegd op 4 september 2018.

15 http://tule.slo.nl/OrientatieOpJezelfEnWereld/F-L38.html, geraadpleegd op 14 oktober 2018 .

16 https://klapuitdeschool.nl/hoorn-bidden-moskee/, geraadpleegd op 4 september 2018.

17 https://www.geenstijl.nl/5142444/het-is-geen-onderwerping-als-het-van-de-leraarmoest/.

18 De Telegraaf, 'Onvrede over moskee-schoolreis', 9 juni 2018.

$19 \mathrm{https} / / /$ cultuurondervuur.nu/zwarte-piet-2015/, geraadpleegd op 15 oktober 2018.

$20 \mathrm{https}$ ://cultuurondervuur.nu/zwarte-piet-2015/, geraadpleegd op 14 oktober 2018, onderstreping in het origineel.

$21 \mathrm{https}: / /$ cultuurondervuur.nu/tag/jerry-afriyie/, geraardpleegd op 14 oktober 2018.

22 https://www.businessinsider.nl/suitsupply-ad-gay-men-backlash-2018-2/?international=true\&r=US, geraadpleegd op 3 september 2018.

23 Hier is niet de plek om dit uitgebreid te bediscussieren, maar we verwijzen wel naar de parallellen met de campagnes van het Italiaanse modemerk Benetton uit de jaren 
1980 en 1990 , waarin afbeeldingen van geracialiseerde mensen bedoeld waren om raciale verschillen te overstijgen, maar daardoor in feite raciale scheidingslijnen juist benadrukten (zie John Solomos, 186 ff.).

24 https://www.ad.nl/nijmegen/demonstratie-in-nijmegen-tegen-posters-suitsupply-het-grenst-aan-porno a63b14be/, geraadpleegd op 3 september 2018.

25 https://www.ad.nl/binnenland/nederland-is-alleen-tolerant-als-je-homo-zijn-promoot a231beo7/, geraadpleegd op 3 september 2018.

26 https://www.ad.nl/binnenland/nederland-is-alleen-tolerant-als-je-homo-zijn-promoot a231beo7/, geraadpleegd op 3 september 2018.

27 https://www.powned.tv/artikel/anti-homoprotest-draait-om-naar-pro-homoprote.

28 ibid.

29 https://www.facebook.com/cultuurondervuur/posts/1824119591040179.

30 https://www.facebook.com/redzwartepiet/posts/1196647803823977?__xts__\%5Bo\%5D=68.ARDgy4wrHbifSOCtYmBPdxABlSMbbPdXxaoYkjOTxzw_mAHbvbxPqDSbWd2uyl3PIwovAioQtDMhouVC5-EAMOHGi5vliNıwBnxUg6aoKZhsi-OK8Jk-us4E89mkJyGmn5HDV-vY4EdW DHIEHKN6XvSa1WWO8-RVRK8ktz4e93hEZJVeT7hujw\&_tn__=-R, geraadpleegd op 10 september 2018 .

31 Iemand als Geert Wilders bijvoorbeeld, is wel een voorstander van het vervangen van artikel 1, waarin gelijkheid voor de wet vastgelegd wordt, door een artikel waarin verwezen wordt naar het primaat van de joods-christelijke humanistische Leitkultur van Nederland, maar bedoelt daar juist niet de Tien Geboden mee. Ook de VVD spreekt over het belang van christelijke waarden in expliciet seculiere termen, zie Van den Hemel 2017b.

32 De actie van hen die de geplande demonstratie in Dokkum van anti-Zwarte Piet betogers in 2017 blokkeerden op de snelweg, kan in dat licht gezien worden als onderdeel van deze ontwikkeling.

\section{Literatuur}

Balkenhol, Markus, Paul Mepschen \& Jan Willem Duyvendak (2016),

The Nativist Triangle. Race, Sexuality and Religion in the Netherlands, in: Duyvendak, Jan Willem, Peter Geschiere \& Evelien Tonkens (eds.) (2016), The Culturalization of Citizenship: Belonging and Polarization in a Globalizing World, New York: Palgrave MacMillan, 97-112.

Boer-Dirks, Eugenie (1993),

Nieuw Licht op Zwarte Piet, in: Volkskundig Bulletin, 19 (1), 1-35.

Boer, Eugenie (2009),

Sint-Nicolaas, een levende legende, in: Koops, W., M. Pieper \& Eugenie Boer (red.), Sinterklaas verklaard, Amsterdam: SWT, 11-34.

Bourdieu, Pierre (1986),

The Forms of Capital, in: Richardson, J. (ed.), Handbook of Theory and Research for the Sociology of Education, Westport, CT: Greenwood, 241-258. 
Duyvendak, Jan Willem (2011),

The Politics of Home: Belonging and Nostalgia in Western Europe and the United States, New York: Palgrave MacMillan.

Duyvendak, Jan Willem, Peter Geschiere \& Evelien Tonkens (eds.) (2016),

The Culturalization of Citizenship: Belonging and Polarization in a Globalizing World, New York: Palgrave MacMillan.

Geschiere, Peter (2008),

Perils of Belonging Autochthony: Citizenship, and Exclusion in Africa and Europe, Chicago: Chicago University Press.

Helsloot, John (2008),

De ambivalente boodschap van de eerste Zwarte Piet (1850), in: Doelman E. \& J. Helsloot (red.), De kleine Olympus. Over enkele figuren uit de alledaagse mythologie, Amsterdam: KNAW Press, 93-117.

Hemel, Ernst van den (2017a),

"Hoezo christelijke waarden?" Postseculier nationalisme en uitdagingen voor beleid en overheid, in: Tijdschrift voor Religie, Recht en Beleid, 8 (2), 5-23.

Hemel, Ernst van den (2017b),

The Dutch War on Easter: Secular Passion for Religious Culture \& National Rituals, in: Yearbook of Ritual and Liturgical Studies, 33, 1-19.

Hemel, Ernst van den (2018),

Postsecular Nationalism: the Dutch Turn to the right \& Cultural-Religious Reframing of Secularity, in: Alma, Hans \& Guido Vanheeswijck (eds.), Social Imaginaries in a Globalizing World, Berlin and Boston: De Gruyter, 249-265.

Mudde, Cas (2007),

Populist Radical Right Parties in Europe, Cambridge and New York: Cambridge University Press.

Roodenburg, Herman (2012),

De 'Nederlandsheid' van Nederland. Een nieuw project aan het Meertens Instituut, in: Volkskunde. Tijdschrift over de cultuur van het dagelijks leven, 113 (2), 203-212.

Solomos, John \& Les Back (eds.) (1996),

Racism and Society, Houndmills, Basingstoke and New York: Palgrave.

Stengs, Irene, (2012),

Nieuw in Nederland: feesten en rituelen in verandering, Amsterdam: Amsterdam University Press.

Veer, Peter van der (2006),

Pim Fortuyn, Theo van Gogh, and the Politics of Tolerance in the Netherlands, in: Public Culture, 18 (1), 111-124. 